\title{
NATIONAL FANTASIES, EXCLUSION, AND THE MANY HOUSES ON MANGO STREET
}

\author{
Lorna L. Perez \\ Buffalo State College
}

Thoreau poses a deceptively simply question when he asks, in Walden: "What is a house?" Sandra Cisneros's The House on Mango Street (1985) revolves around this very question as the narrator, Esperanza Cordero, consistently articulates a profound need to one day own a home of her own. At the heart of Esperanza's longings are foundational questions about what it means to belong to a place, a question that is heightened by Esperanza's status as a poor child of immigrant and ethnic parents. Given the specificities of Esperanza's subject position, the question of what it means to belong to a place, and the symbolic association of houses with belonging, takes on a more complicated meaning, as it speaks directly to the foundational assumptions that underlie the house and its relation to the American imaginary.

At the center of this consideration is the loaded and metaphorically rich association of houses with American identity, and more particularly the story of upward mobility that is most commonly referenced through iconic representations of the post-World War II American Dream. While it may be tempting to read Esperanza's longing for a house of her own as a gesture towards the immigrant-makes-good narrative that is associated with the American Dream, I will contend that the meaning of the house in this novel is, at best, an ambivalent one. The text is populated with multiple houses - some real and some imagined - that, when taken in conjunction with one another, provide a stark critique of gender, domesticity, and ultimately national inclusion. The House on Mango Street does not reaffirm the comforting ethos of the American Dream rather it uses its most profound symbol-the house-to reveal its unstable and violent foundations. ${ }^{1}$

1 I understand the American Dream here as the particular narrative that emerges after the second world war, when suburbanization, for a variety of complex reasons, began to take hold in American culture. This particular narrative places emphasis on rugged individualism and hard work and manifests itself in the iconic suburban home, in many instances the hardearned reward of soldiers returning from war. I am, however, also interpreting the American Dream as the twentieth century manifestation of a much longer narrative of settlement, home building, and home making and their relationship to the establishment of the American nation state. 
The house is one of the most foundational and profound symbols in American literature. As Marilyn Chandler (1991) has pointed out:

Our literature reiterates with remarkable consistency the centrality of the house in American cultural life and imagination. In many of our major novels a house stands at stage center as a unifying symbolic structure that represents and defines the relationships of the central characters to one another, to themselves and to the world and raises a wide range of questions. . .(1)

In attempting to answer what a house is in the context of The House on Mango Street, we must interrogate what it means to lay claim to space and place, as doing so requires a radical reconfiguration of who can and cannot "belong" to the nation itself. For a young, poor, non-white, woman to try and demand a space where she belongs outside of patriarchal, racist, and classist culture requires radically rethinking and restructuring what home and belonging mean. Reading the houses on Mango Street critically allows us to begin to envision this difference, as the "real" space of the novel constantly clashes with the imagined space away from it, and the collision reveals the foundational violence of our national narrative.

Overwhelmingly, when critics and scholars have analyzed The House on Mango Street they have done so under the premise that there is one primary house in the text. This is a fundamental error; the novel is full of houses, including the house of the title, all of which draw attention to the pervasive sense of loss, loneliness, and marginality that houses themselves are meant to counter. Perhaps one of the great ironies of The House on Mango Street is that the novel is not a text about being at home in the world, or belonging to a place; rather it is about the ways that poverty and violence raise specters of belonging, even as they deny the materiality that should attach to such things.

Of all the houses that populate this text, the two most important are the house the title of the text names, the sad, red, house on Mango Street, and the dream house (she calls it a "real" house) to which the protagonist Esperanza Cordero wants to escape. Between these two houses, are the myriad other houses that dot the textual landscape; houses that are marginal, invisible, and filled with teeming and forgotten life. These are houses that are spaces of shame and loss, structured around patriarchal domesticity, and marginalized by racist, classist hegemony. The sad, red, house on Mango Street is the symbolic locus of these haunted, broken houses made visible, and is a profound critique of the way that poverty, ethnicity, and gender merge together, desiccating the lives of the people within them. While the sad, red, house on Mango Street is symbolic of loss, the text also constructs, through Esperanza's longing, an alternative 
space. The "real" house that Esperanza dreams of having — and the house that she must leave Mango Street to achieve-is one that shelters other kinds of possibilities: possibilities of feminist empowerment, possibilities for escape and the promise of belonging. I argue that understanding the sad, red house on Mango Street in light of Homi Bhabha's notion of the unhomely, and then similarly reading the house Esperanza imagines away from Mango Street in Gaston Bachelard's terms of felicitous space allows us to understand how the construction of one is occasioned through the lack of the other. In dreaming up the house away from Mango Street, Esperanza engages in a radical politics which reconfigures the grounds of community, domesticity and belonging, though she can only do this by exposing that which remains hidden and obscured by the foundations of the sad, red house, here a derivative symbol of the American Dream.

\section{The Unhomely House on Mango Street}

The text opens with the vignette entitled "The House on Mango Street." The first line signals important themes that will run throughout the text: nomadism, homelessness, and un-belonging: "We didn't always live on Mango Street. Before that we lived on Loomis on the third floor, and before that we lived on Keeler. Before Keeler it was Paulina and before that I can't remember. But what I remember most is moving a lot. .." (Cisneros 3) The unrelenting relocations immediately establish a profound sense of dislocation that permeates the entirety of the text, as Esperanza consistently articulates a sense of homelessness and lack. The precariousness of her family's living conditions, and more specifically their multiple relocations before buying the house on Mango Street, suggests instability and vulnerability, a sense that is further underscored by their status as poor and Latino. Home-ownership-that cornerstone of the American narrative-looms large and is a way of solidifying her family's belonging to a place.

The actuality of the sad, red, house, however, is a terribly inadequate fulfillment of that promise:

But the house on Mango Street is not the way they told it at all. It's small and red with tight steps in front and windows so small you'd think they were holding their breath. Bricks are crumbling in places, and the front door is so swollen you have to push hard to get in. There is no front yard, only four little elms the city planted by the curb. Out back is a small garage for the car we don't own yet and a small yard that looks smaller between the two buildings on either side. There are stairs in our 
house, but they're ordinary hallway stairs, and the house has only one bathroom. (Ibid., 4)

The house on Mango Street has no resemblance to the iconographic house of the American Dream; it lacks every significant feature that would signify its status as a representation of the family's belonging to a place and instead is representative of one more step up the scale of poverty and disenfranchisement. The house, with its descriptions of lackthe swollen floors that barely allow entrance, the crumbling bricks, the garage for the car they do not have-marks absence, not presence and, moreover, invokes through its inadequacy the image of the house they do not have, the house of middle-class material comfort. The house on Mango Street reminds both the reader and Esperanza that owning the house is not the same thing as belonging to a place. In fact, owning the house on Mango Street does not create a sense of being at home, it instead creates a sense of being un-homed.

Homi Bhabha (1992), borrowing from Freud describes being unhomed (and the un-homely) in the following way:

To be unhomed is not to be homeless, nor can the "unhomely" be easily accommodated in that familiar division of social life into the private and the public spheres. . .In a feverish stillness, the intimate recesses of the domestic space become sites for history's most intricate invasions. In that displacement the border between home and world becomes confused; and, uncannily, the private and the public become part of each other, forcing upon us a vision that is as divided as it is disorienting. (141)

The unhomely in this sense is not as simple as a broken down house that fails to meet up to the fantasy that is projected unto it. Rather, the unhomely in reference to Mango Street reveals the way that the house becomes a site of deprivation and exclusion. The materiality of the houseits too tight steps, the windows holding their breath, the ordinary hallway stairs - mark it as other. In this house the family has not succeeded in achieving the American Dream, they have, instead, acquired a derivative version of it that speaks to the intimate invasions of history. More specifically, this house, situated in an impoverished and peripheral neighborhood, populated by poor people of color, and characterized by violence and lack, creates an unhomely answer to the fantasy of national inclusion. 
Domesticity, Confinement, and the Communal Gaze: The Many House on Mango Street

Cisneros draws constant attention to the potential violence of homespace by interrogating the very foundations of homeliness-the domestic-as a site of confinement for women. Doreen Massey (1994) has convincingly argued that our conceptions of space and domesticity are tied into patriarchal modes of control. She writes:

One of the most evident aspects of this joint control of spatiality and identity has been in the West related to the culturally specific distinction between public and private. The attempt to confine women to the domestic sphere was both a specifically spatial control and, through that, a social control on identity. (179)

In Cisneros's text this social control is determined by cultural and phallocentric norms that confine women in prison-like homes, wherein identity and self-hood become annihilated by dual registers of disenfranchisement: the women of Mango Street are marginal as women; equally, they are marginal as members of a poor, and all but invisible, "other" community. In interrogating the meaning - and the possibly violent implications of domesticity-Cisneros's text problematizes the everyday notion of the public $\mathrm{v}$. private by demonstrating the ways that public space (the street, the neighborhood) constitute, and at times, invades domestic space. The unhomeliness of the house on Mango Street does not magically end at the front door with the too-tight steps, rather the unhomeliness of the home is, in part, created through navigating the public space of urban, poor, neighborhoods, and the profound implications this has for women.

Cisneros makes this clear by situating the reader's gaze on the landscape and the community that the house on Mango Street is situated within. By making the focus of the text the external world of Mango Street (as opposed to the internal world of the home), Cisneros creates a community narrative that critiques structural systems of poverty, disenfranchisement, and marginality. Though the title of the text implies a focus on domesticity by privileging the house, it is notable and important that Esperanza's storytelling does not center on the home as a site of refuge, but rather upon the house as a readable aspect of a landscape that constitutes it. Contrary to what the title might suggest, the stories that make up The House on Mango Street are not the stories of the Cordero family per se, nor are they the story of the internal life of the Cordero home. Rather, in making The House on Mango Street the narrative of a community and a public identity associated with place, the ground of the narrative shifts away from models of individual American exceptional- 
ism, epitomized by the singular house, and focuses instead on the failures of this ideology, as symbolized by the marginalization of the entire community. Monika Kaup (1997) characterizes Cisneros's shift from the internal home into the public street in the following way:

Cisneros . . . expand[s] the focus from a single, isolated house to the street. In so doing she diminishes the status of the individual and reintroduces the communal perspective - bringing us back to Chicano nationalism's concerns with the collective. Through the street, Cisneros reintroduces a collective Latino public space, the urban equivalent of homeland. (390)

For Kaup, the street and the outward gaze create a collective space that functions as a homeland, though even here the sense of the unhomely haunts the space. Esperanza is neither "at home" in her house, nor is she entirely "at home" in the collective space of the street. The street as homeland becomes a fairly precarious position, since it first signifies metaphoric homelessness, and secondly is infused with a sense of (barely) contained danger; the street/public space is as much a site of intimate violations as the house is, as vignettes like "The Family of Little Feet" and "Red Clowns" make clear through their emphasis on sexual violence and danger. The sense of the unhomely registers in terms of both the private (house), and the public (the street), indicating that safety, belonging, and acceptance are, in the best circumstances, only tangentially available to marginalized communities and their access to the national fantasy of the American Dream. In this context, neither the world, nor the home provides a refuge from the stigmas of poverty and violence.

The fact that the house located on Mango Street is only one of many houses is important as it creates a community narrative as opposed to an individual one. Moreover, using the community as the starting point for the narrative moves the text away from discourses of individual success or failure and points instead to the systemic violence of an ideology that at its core seeks to create spaces of safety and acceptance precisely through the exclusion of the poor and people of color. Indeed, as the white flight of the middle of the twentieth century reminds us, urban centers were abandoned in order to establish homogenous economic and racial communities in the American suburbs. While suburbanization is tied intimately in with the symbolic creation of the American Dream, it assumes as one of its foundational premises the necessity of using physical space as a weapon. Much in the same way as the house located on Mango Street creates its own dream image, and that dream image-the fantasized house-in turn conjures its shadow double in the Mango Street house, so too do the suburbs conjure the abandoned inner city, and 
the inner city becomes the ghostly double, the hidden reminder, of suburban comfort.

This duality is further seen through the structure of the house itself as a symbolic construct. The unhomeliness of Esperanza's neighborhood is dually constructed as a public and private entity, which themselves constitute and construct one another. The house on Mango Street is both a public entity - a readable aspect of the landscape - even as it is also a private entity that erects a boundary between the internal life of its inhabitants and the public space of the street. Esperanza's charting of her neighborhood, her mapping of space, obliterates these easy boundaries by showing us that which remains hidden inside houses, and by equally showing that which remains hidden even in public. By revealing the private-abuse, loss, imprisonment, abandonment, violence- she robs the house of one of its main functions: to protect its inhabitants. In deconstructing the house in this way, Cisneros reveals a darker function of houses in the barrio; they contain and confine as opposed to protect or shield, and as a result exposes the unhomeliness lurking in their foundations.

Esperanza makes the domestic the site of public discourse by interrogating the implications of being a woman in a public space. The urban homeland that is available to women, through the auspices of collective cultural experience is hardly, as the stories of the women of Mango Street remind us, a liberating space. As Annie O. Eysturoy (1996) has put it:

A common denominator uniting almost all the different women Esperanza portrays is, not only their entrapment in oppressive sociocultural circumstances, but their internalization of a definition of self that is determined by phallocentric cultural values. They are thus not only confined within their own house, but also confined by their own minds, by the conditioned limitations of their own self-perceptions. Their lives and actions, dominated by fathers and husbands, are physically and psychologically entrapped within oppressive patriarchal structures, and they can envision themselves only in the seemingly inescapable roles of future wives and mothers. (102)

Esperanza's articulation becomes an act of conjuring that connects her story to the stories of the past, the stories of the voiceless women lost in the anonymity of the domestic and to the transformative power of storytelling itself. The stories of the women of Mango Street serve as cautionary tales for Esperanza, even as the act of telling their stories allows her to articulate a future for herself removed from the phallocentric standards of feminine possibility. 


\section{Chicana Feminist Architecture: Renovating THE American Dream}

For many of the women of her community-confined by the patriarchal norms of their culture and crippled by poverty and racism-there is very little room for negotiating identities or spaces of agency. In acknowledging the limits of patriarchal domesticity, where in the best circumstances women are thwarted and in the worst they disappear under a constant barrage of violence, Esperanza articulates a need for a different kind of life. Gloria Anzaldúa (1987) has described these limits and possibilities as follows:

The culture expects women to show greater acceptance of, and commitment to, the value system than men. The culture and the Church insist that women are subservient to males. If a woman rebels she is a mujer mala. If a woman does not renounce herself in favor of the male, she is selfish. If a woman remains a virgen until she marries, she is a good woman. For a woman of my culture there used to be only three directions she could turn: to the Church as a nun, to the streets as a prostitute, or to the home as a mother. Today some of us have a fourth choice: entering the world by way of education and career and becoming self-autonomous persons. A very few of us. As a working class people our chief activity is to put food in our mouths, a roof over our heads and clothes on our backs. Educating our children is out of reach for most of us. Educated or not, the onus is still on woman to be a wife/mother - only the nun can escape motherhood. Women are made to feel total failures is they don't marry and have children. (39)

Esperanza, the young dreamer and artist, sees women all around her who have not escaped from these roles. As a barely working-class Latina, Esperanza's desire for a home of her own as well as her determination to achieve these things through her books and her papers, signals the rare path that Anzaldúa articulates above. Given the rarity of her choices and the difficulty of achieving them, it is important to turn to the symbolic locus of this desire; the home of her own away from Mango Street.

The creation and projection of the house away from Mango Street arises precisely in response to the unhomeliness of both the Mango Street house and the marginal neighborhoods of Esperanza's childhood. These spaces signify a profound exclusion and lack: the lack of a house she can point to, and a home that she can feel she belongs to, demarcate and delimit the boundaries of her viable participation within the national nar- 
rative that is invoked by the American Dream. The symbolic force of the family's purchase of their own home does not assuage this sense of inadequacy and lack of belonging; rather it has the inverse effect of heightening it.

In response to her family's inability to move beyond the material confines of their poverty to provide Esperanza with a "real house", she instead turns to a strategy that is both resilient and empowering: she imagines a real house for herself away from Mango Street. Dream houses, in fact, haunt this text as the specters of the promise that lie just past the confines of the family's material conditions. The first of these houses is the house that her parents promise her they would one day have, and the second is the house that Esperanza herself is committed to occupying. These two dream houses, when contrasted with one another, combine to reveal the limitations of the national narrative - the idea that hard work, self-sacrifice, frugality and self-sufficiency will ultimate earn one a place within the nation, exemplified by home-ownership- as well as the limitations of radical action configured outside the space of patriarchy. While the dream house of Mr. and Mrs. Cordero is brought into stark contrast by the realities of the House on Mango Street, Esperanza's dream house is brought into similar contrast by the limitations of ideology in relation to lived experience.

The house that the Cordero family dreams of occupying-the house they promise Esperanza that the Mango Street house so dismally fails to compare with-is described as follows:

They always told us that one day we would move into a house, a real house that would be ours for always so we wouldn't have to move each year. And our house would have running water and pipes that worked. And inside it would have real stairs, not hallway stairs, but stairs inside like the houses on T.V. And we'd have a basement and at least three washrooms so when we took a bath we wouldn't have to tell everybody. Our house would be white with trees around it, a great big yard and grass growing without a fence. This was the house Papa talked about when he held a lottery ticket and this was the house Mama dreamed up in the stories she told us before we went to bed. (4)

The house that the family dreams up is the iconic suburban home; it promises rootedness and permanence and acts as the symbolic manifestation of acceptance into the space of the nation. For the Corderos, like many immigrant families, the achievement of the home of one's own signals an adherence to those typically "American" characteristics: hard work, self-determination, and self-sufficiency. 
The Cordero's longing for the fantasy house and their dream of being able to attain it are seductive fictions. The replacement of the dream house with the Mango Street house marks the limitations of a fantasy which at its core relies on the historic and contemporary disenfranchisement of large groups of people - the poor, people of color, women - to sustain it. It further demonstrates, through the contrast between the sad, red house and its normal hallway stairs with the dream house and its inside stairs, the limitations of upward mobility achieved through hard work and sacrifice.

In response to the failures of the American Dream's model of hard work creating upward mobility, as well as the limitations of the patriarchal house as retreat and safety, Esperanza declares that she has to have a house of her own one day, one that she can point to. She feels the necessity of outrunning the shame of poverty, of marginality, and the drudgery of endless labor for limited gain. She knows she has to create a different alternative for the foundations of her life. She begins with the space of her own dream house:

Not a flat. Not an apartment in back. Not a man's house. Not a daddy's. A house all my own. With my porch and my pillows, my pretty purple petunias. My books and my stories. My two shoes waiting beside the bed. Nobody to shake a stick at. Nobody's garbage to pick up after. Only a house quite as snow, a space for myself to go, clean as paper before the poem. (Ibid., 108)

The house is, first and foremost, a feminine space that simultaneously restructures and re-constitutes the domestic and the feminine; it is filled with the markers of a quiet and thoughtful domesticity that nurtures creative and intellectual activity and as such is removed from the confines of domestic drudgery that patriarchal values demand. The repetition of "nobody" reinforces the solitude that the space of the dream house affords, echoing the first lines of the vignette. The kind of belonging that Esperanza longs for throughout the book is found by belonging, first and foremost, to herself.

Whereas the house located on Mango Street is characterized by a pervading sense of the unhomely, the House Away from Mango Street is characterized by what Gaston Bachelard (1969) calls "felicitous space":

Indeed, the images I want to examine are the quite simple images of felicitous space. In this orientation, these investigations would deserve to be called topophilia. They seek to determine the human value of the sorts of space that may be grasped, that may be defended against adverse forces, the space we love. For diverse reasons, 
and with the differences entailed by poetic shadings, this is eulogized space. Attached to its protective value which can be a positive one, are also imagined values, which soon become dominant. Space that has been seized upon by the imagination cannot remain indifferent space subject to the measures and estimates of the surveyor. It has been lived in, not in its positivity, but with all the partiality of the imagination. Particularly, it nearly always exercises an attraction. For it concentrates being within limits that protect. In the realm of images, the play between the exterior and intimacy is not a balanced one. (xxxv-xxxvi)

In Bachelard's articulation of the house as object of poetic consideration, he points to the way that the lived experience of the house intersects with the imagination. While his consideration of the house certainly focuses on the house as a privileged site, he takes his subject to be one that is shaded both by experiences and imagination. The house, particularly the house of childhood, is not an entirely romanticized entity, insofar as it is an entity that is always brought to mind through memory-hence its status as eulogized space.

While Cisneros and her critics have understood Bachelard's position and treatment of the house through the lens of privilege, it is worth noting that Bachelard himself is undertaking to examine an ontological image and its deep reverberations as a poetic entity, an enterprise which is self-consciously aware of, and in many ways relies upon, the romanticization of space to maintain it. ${ }^{2}$ Bachelard is well aware that the house carries its own contradiction within it, that private and public are implicated in one another beyond messy dialectical divisions, and that the house of our dreams oft-times does not correspond to the houses of our memory and imagination.

In some ways, this is the fact that allows for the division between the house located on Mango Street-the house of the unhomely - and the House Away from Mango Street - the house of felicitous space- to implicate, contradict, and collapse into one another. For the protagonist of Cisneros's text, memory and imagination are not sufficient to re-construct the house located on Mango Street into a house of felicitous space where Esperanza can be and be. The jarring reality of the Mango Street house is too real and discordant to allow for this. Instead, Esperanza must create an entirely new house, one that is informed by her subject position

2 See Robin Ganz "Sandra Cisneros: Border Crossing and Beyond", as well Martha Satz "Returning to One's House: An interview with Sandra Cisneros" for Cisneros's discussion of Bachelard's influence. 
and constructed, to paraphrase Gloria Anzaldúa, with her feminist architecture.

While the solitude and feminine-centric construction of the house away from Mango Street seems, at first glance, to create a space that by its very nature excludes the public and the community, Esperanza's imagined House Away from Mango Street actually establishes a space for the articulation of community outside traditional structures of kinship and belonging, as she imagines the house as a space that can act as a shelter for others who find themselves homeless, either literally or metaphorically. The first example of this is when Esperanza imagines offering Sally a safe space within her house of dreaming:

Sally, do you sometimes wish you didn't have to go home? Do you wish your feet would one day keep walking and take you far away from Mango Street, far away and maybe your feet would stop in front of a house, a nice one with flowers and big windows, and steps for you to climb up two by two upstairs to where a room is waiting for you. And if you opened the little window latch and gave it a shove, the windows would swing open, all the sky would come in. (82-83)

Sally, in obvious and painful ways, suffers from the same kind of unhomeliness that characterizes Esperanza's longing, and in response to this, Esperanza offers her an imaginative place in the House Away From Mango. By replacing Sally's geography, by literally transporting her from her painful walk to her father's home that she cannot come out of, to the steps of a nice house, Esperanza places her within the context of her own desire to one day just walk away from Mango.

More importantly, though, Esperanza replaces the unhomeliness that marks Sally with an offer of felicitous space, a space that has the potential to save her. As Sally arrives at Esperanza's dream house and is able to climb the stairs two by two, to a room where she can sleep and dream in peace, she is climbing into the space of her own autonomous life. Esperanza's dream house offers a place of acceptance and love and becomes an important, if only visionary, alternative to the male dominated home. The limits of this home, however, are immediately clear, as Sally opts, not for her own house, or even the possible vision of a feminine space dictated by feminine-centric creativity and acceptance, but instead acts according to the only avenue she believes available to her (marriage), frighteningly reaffirming the phallocentric values that Esperanza's bourgeoning feminist ethics reject.

Though Esperanza's House Away from Mango Street registers as a communal space, as Sally demonstrates, this communal status depends on the ability or desire of the saved to move beyond the confines of their 
own ideological constructs- a requirement that is not always feasible. The very nature of the ideologies that the House Away from Mango is supposed to stand in opposition to is that they are totalizing, absolute, and nearly inescapable. These are limitations that Esperanza cannot understand, as her second articulation of communal space suggests.

The second vignette that suggests that Esperanza views the house away from Mango Street as a communal space is "Bums in the Attic", a short piece that articulates both the fragmentation that attends to class and upward mobility as well as the limitations of Esperanza's vision of escape:

People who live on top of hills sleep so close to the stars they forget those of us who live too much on earth. They don't look down at all except to be content to live on hills. They have nothing to do with last week's garbage or fear of rats. Night comes. Nothing wakes them but the wind. One day I'll own my own house, but I won't forget who I am or where I came from. Passing bums will ask, Can I come in? I'll offer them the attic, ask them to stay, because I know how it is to be without a house. Some days, after dinner, guests and I will sit in front of a fire. Floorboards will squeak upstairs. The attic grumbles. Rats? They'll ask. Bums, I'll say, and I'll be happy. (Ibid., 86-87)

The geography of this vignette is important, as Esperanza describes a topography in which some are closer to the heavens and have in their service those who are too bound to the earth. The relevance of this geographical hierarchy is important because it obviously mirrors class constraints and additionally reveals Esperanza's longing for ascent. She is weary of the promise of moving "up" being tempered by the reality of lateral movement-a slightly better flat, one with running water; a slightly better house that still has plain, old, hallway stairs-a movement up the metaphoric hill measured out in inches, not feet. Esperanza knows it will take more than longing and more than promises to become one of the people on the hill.

In this moment, Esperanza recognizes the truth of conquest and the emptiness of the promise of the American Dream. The idea that hard work alone will give one access to the house on the hill is underscored by all of the people around her who work and nonetheless have little hope of upward mobility. In "Papa who Wakes up Tired in the Dark", for example, we learn that Esperanza's father wakes up tired, in the dark, to go to work in the gardens of the house on the hill; he attends to the promise of upward mobility, even as he is situated in its periphery. For those excluded from the discourse of the nation - those who do not occupy the 
house on the hill, but attend to it - the American dream is tempered by metaphoric or literal homelessness, rats, and last week's garbage. The working migrant's access to the house on the hill, to the promise of the nation, is limited and confined if one relies simply on the notion of hard work to succeed. Hard work will get you to the edge of the property, clinging to a lottery ticket. Something else is required to occupy the master's house.

While the first half of "Bums in the Attic" points to the limitations of the discourse of the American Dream and reinforces, yet again, the sense of longing, marginality, and homelessness that permeate the text, the last half of the vignette speaks more directly to the vision Esperanza has for the house she intends to own one day. The two descriptions of the dream house, "A House of My Own" and "Bums in the Attic" tell us that while she desires the space of quite dreaming, the Bachelardian house shielding the daydreamer, she also knows who and what she is; she knows where she come from and in her words, "understands what it means to be without a house." As Maria Antonia Oliver-Rotger (2010) has pointed out:

The middle class, feminist, aesthetic implications of Esperanza's words are ineludible, but they have to be considered in relation to her incipient collective social consciousness. Her freedom as a woman and as an artist together with the social reality of those "who live too much on earth" will be the constitutive elements of her aesthetics. . .(290)

As a result, the home she imagines has to encompass contradictory impulses; it needs to be both a space of solitary, creativity, with room enough to dream and dream, even as it also has to be a house that can shelter the marginal members of her own community.

The solution to this seeming contradiction lies in the foundations of Esperanza's bourgeoning feminist ethics. In asserting her refusal to share her space with the requisite children and husband, she gives herself room enough to take on another role. By allowing the bums to live in the attic, Esperanza enacts a community-oriented ethic that begins the process of redefining femininity. Seemingly, if Esperanza is not burdened with housekeeping and child rearing, not only will she have time enough to write (to be and be) she will also have the resources to better attend to the marginal members of her community. Her house of writing is not a solitary house, it is a house peopled by the less fortunate. This is an important symbolic moment, as Esperanza seems to acknowledge that education (books and papers) have the radical potential to reshape communities of color, assuming that the tools they provide are not used in isolation. The upward mobility that education affords allows Esperanza 
to literally house her community and offer a counterweight to the prevailing sense of homelessness that accompanies poverty and marginalization.

In re-shaping the idea of what a dream house is, and more importantly what it does, Cisneros provides an important renovation to the structure of the American Dream. By thinking of houses not as sites of retreat, or the symbolic locus of heteronormative, phallocentric values, but rather as spaces that have potential to house community, and moreover as spaces that can help create discourse, she carves out a space of belonging that is born of the unhomely. Cisneros brings that which is hidden to light: she exposes what marginality, poverty, violence, racism, and invisibility do to communities; she exposes the potential for the house to act as a prison rather than a refuge; she destabilizes the division between the house and the street, revealing the ways that each construct and constitute one another. More than this though, by using the house as a potential incubator of discourse, she refigures what feminine domestic space can be. The House on Mango Street reveals that which remains hidden in the American Dream, and in doing so, it stakes a claim for itself. By giving voice to her community, and by offering to house it in her dream space, Esperanza re-imagines what home can mean, and provides alternative structures for attaining it.

\section{Conclusion}

The House on Mango Street is a novel that is full of houses: houses that are sources of shame, houses that alienate and marginalize, houses that act as prisons, and finally imaginative and anticipated houses that act as a counter to these forces. By reading the House on Mango Street with an eye towards these many houses, we can begin to see that which remains hidden: the unhomely within the foundation of the national fantasy epitomized by the American Dream and its subsequent suburban fantasy; the marginality and invisibility of impoverished and racially demarcated communities; the potential violence of domestic space; the implication of the public and the private in the creation of spaces. Moreover, only when considering the ways that the multiple houses conjure and connect with one another can we begin to appreciate the radical potential that Esperanza's dream house away from Mango Street provides. She reshapes the house on Mango Street and the House Away from Mango Street by recognizing the home she has been denied and the one she will nonetheless create. By imagining her dwelling in terms of femininity, privacy and community, Esperanza sets up a space outside the traditional confines of family, home, and even nation. If the house is metaphoric of the nation, the nation Esperanza imagines is a performative one in which the marginal and vulnerable are housed and sustained outside traditional kinship or 
community networks. With her feminist architecture, Esperanza imagines a radically revised dream that can accommodate difference and ambiguity instead of totalizing or foreclosing on it.

\section{BIBLIOGRAPHY}

Anzaldua, Gloria. 1987. Borderlands/La Frontera: The New Mestiza. San Francisco: Aunt Lute Books.

Anzaldua, Gloria Moraga, Cherrie ed. 1983. This Bridge Called My Back: Writings by Radical Women of Color. 2nd ed. New York: Kitchen Table.

Bachelard, Gaston. 1969. The poetics of space. Boston: Beacon Press. Bhabha, Homi. 1992. "The World and Home." Social Text 31/32:141153.

Chandler, Marilyn R. 1991. Dwelling in the text : houses in American fiction. Berkeley: University of California Press.

Cisneros, Sandra. 1985. The House on Mango Street. Houston: Arté Publico Press.

Cisneros, Sandra, Satz, Martha. 1997. "Returning to One's House: An Interview with Sandra Cisneros." Southwest Review 82 (2):166-185.

Cruz, Felicia J. 2001. "On the "Simplicity" of Sandar Cisneros's House on Mango Street." Modern Fiction Studies 47 (4):910-946.

Doyle, Jacqueline. 1994. "More Room of Her Own: Sandra Cisneros's The House on Mango Street." MELUS 19 (4):5-25.

Eysturoy, Annie O. 1996. Daughters of self-creation : the contemporary Chicana novel. 1st ed. Albuquerque: University of New Mexico Press.

Ganz, Robin. 1994. "Sandra Cisneros: Border Crossings and beyond." MELUS 19 (1):19-29.

Lorde, Audre. 1981. "The Master's Tools Will Never Dismantle the Master's House." In This Bride Called My Back: Writings by Radical Women of Color, edited by Cherrie Moraga, Anzaldua, Gloria, 98-101. Watertown, Mass: Persephone Press.

Massey, Doreen B. 1994. Space, place, and gender. Minneapolis: University of Minnesota Press.

Oliver-Rotger, Maria Antonia. 2010. “"Homeplaces and Spaces of Their Own“.” In Critical Insights: The House on Mango Street, edited by Maria Herrera-Sobek, 285-324. Pasadena: Salem Press.

Rodriguez, Juan. 1984. "The House on Mango Street by Sandra Cisneros." Austin Chronicle, August 10. 
Sanborn, Geoffery. 2001. "Keeping Her Distance: Cisneros, Dickinson and the Politics of Private Enjoyment." PMLA 116 (5):1334-1348.

Sanchez, Rueben. 1995. "Remembering Always to Come Back: The Child's Wished-for Escape and the Adult's Self-Empowered Return in Sandra Cisneros's House on Mango Street" Children's Literature 23:221-241. 